\title{
Temperature Based Control of Ventilation System for Optimum Climate in Tomato Greenhouse
}

\author{
NY Dahlan', Aminuddin Idham Halid², T Juhana Hashim ${ }^{3}$, SZ Sakimin ${ }^{4}$ \\ ${ }^{1,2}$ Faculty of Engineering Universiti TEknologi MARA (UITM), Shah Alam, Selangor, Malaysia \\ ${ }^{3,4}$ College of Engineering, Universiti Tenaga Nasional, Putrajaya Campus
}

\begin{abstract}
Article Info
Article history:

Received Jun 5, 2018

Revised Aug 1, 2018

Accepted Aug 9, 2018

\section{Keywords:}

Greenhouse system

energy savings

control algorithm.

ABSTRACT

Tomato has been grown successfully in highlands of Malaysia. However, the production does not meet the demand in the large market due to problem related to climate change and lack of smart control mechanism for the tomato crop to grow healthily in the micro climate. Tomato requires optimum temperature to ensure a good quality fruit production especially under greenhouse system environment. This paper presents an optimum control mechanism for ventilation system in a greenhouse to minimize the energy consumption and meet the temperature requirement for lowland tomato. The control mechanism is tested on a tomato greenhouse system located in Universiti Putra Malaysia (UPM), Serdang. The ventilation system in the greenhouse comprises of six exhaust fans and two axial fans. Results show that the proposed control mechanism on the ventilation system is able to maintain the desired temperature for lowland tomato at lower energy consumption. With the automatic control of the ventilation system, an average of $65.8 \%$ of energy consumption was saved from the greenhouse as compared to baseline energy without the control system.
\end{abstract}

Copyright $\odot 2018$ Institute of Advanced Engineering and Science. All rights reserved.

\section{Corresponding Author:}

NY Dahlan

Faculty of Engineering Universiti TEknologi MARA (UITM),

Shah Alam, Selangor, Malaysia

Email: nofriyenita012@ppinang.uitm.edu.my

\section{INTRODUCTION}

In the past few years, modern technology has emerged in the agriculture field for a precision agriculture and food security such as greenhouse system. Precision agriculture concentrates on providing the means for observing, assessing and controlling agricultural system to maintain production quality [1]. The greenhouse is a manmade solution to surpass a suitable ecosystem to grows crop rapidly. Many farmers have built greenhouse for their plant to overcome the climate change issue. Although technology advancements offer innovative solutions for specific issues, achieving optimal management of overall greenhouse is generally difficult [2]. Greenhouse structure is designed to allow as much as light to enter inside the greenhouse area causes the growing environment experiences a significant influence from a fluctuation climate conditions. Solar radiation has the most impact on growing environment, resulting the major challenge to maintaining the optimum growing temperatures for the crops [3].

Most of the crops are very sensitive to the temperature, humidity and moisture. The major challenge in lowland crop is hot temperature. The purpose of using the greenhouse in the lowland is to protect the crop from high temperature, insects, rain and disease. For a sustainable agriculture, the climate inside the greenhouse must be controlled to the desired requirement for the plant or crop to growth healthily. This paper proposes a system where the temperature can be controlled automatically to achieve the optimum requirement for tomato cultivation. 
Tomato is a worldwide important food and the most widely cultivated crops in the world [4]. Greenhouse tomato production has attracted farmers to produce a marketable production as the demand is now higher than supply. Greenhouse tomato requires attention on a consistent basic requirement. Tomato cannot be planted and then left-out for few days or week without proper observation because there are very sensitive [5]. Climate is the most important factors when planting tomato and tomatoes are warm season crop [6]. Tomatoes also sensitive to the frost and are intolerant of very low temperatures [7]. Temperature are the key factor which is used to control crops growth [8] and flowering [9]. Temperature below $10^{\circ} \mathrm{C}$ and above $38^{\circ} \mathrm{C}$ may affect plant tissue hence slowing down crop's physiological activities. The optimum range of temperature is $21-24^{\circ} \mathrm{C}[10]$.

Tomato plant reacts to temperature changes during the growth cycle as shown in Table 1 . Tomato plant can growth well at temperature above $30^{\circ} \mathrm{C}$ but may have bad effect on fruit set [6]. For the tropical lowlands, the minimum temperature at night must above $21^{\circ} \mathrm{C}$ to avoid the fruit abortion [11]. When the temperature is higher than $35^{\circ} \mathrm{C}$, the surface of pollen grain and stigma may dry out and causes lower quality of fruit set. On the other hand, exposure to high temperature above $40^{\circ} \mathrm{C}$ can damage both of ovules and pollen production of tomato [12]. The optimum range for lowland tomato to growth healthily is between $18^{\circ} \mathrm{C}$ to $32^{\circ} \mathrm{C}[18]$.

Table 1. Required temperature ranges for optimum tomato production [6]

\begin{tabular}{|l|c|c|c|}
\hline \multirow{2}{*}{$\begin{array}{l}\text { Development } \\
\text { Stage }\end{array}$} & \multicolumn{3}{|l|}{ Temperature $\left({ }^{\circ} \mathrm{C}\right)$} \\
\cline { 2 - 4 } & Minimum & Optimum & Maximum \\
\hline Germination & 11 & $16-29$ & 34 \\
\hline $\begin{array}{l}\text { Vegetative } \\
\text { Growth }\end{array}$ & 18 & $21-24$ & 32 \\
\hline Fruit- Night & 10 & $14-17$ & 20 \\
\hline \multicolumn{1}{|c|}{ - Day } & 18 & $19-24$ & 30 \\
\hline $\begin{array}{l}\text { Red } \\
\text { Colouring }\end{array}$ & 10 & $20-24$ & 30 \\
\hline $\begin{array}{l}\text { Yellow } \\
\text { Colouring }\end{array}$ & 10 & $21-32$ & 40 \\
\hline Cold Damage & & Under 6 & \\
\hline Frost Damage & & Under 1 & \\
\hline $\begin{array}{l}\text { Terminal } \\
\text { Damage }\end{array}$ & & -2 & \\
\hline
\end{tabular}

Ventilation of greenhouse is about exchanging air inside the greenhouse with the air taken from outside the greenhouse. The exchange of air may be by natural that caused by wing pressure or thermal or by forced air to exchange by mechanical means such as fan. The main reason for ventilation is to control high temperature caused by solar irradiance [13]. The air in the greenhouse must be mixed to prevent air stratification and to reduce temperature and also to minimise fungal disease incidence by promoting faster drying of foliage [14].

Some greenhouse is ventilated by natural vent in the roof but usually unsatisfactory due to rapid temperature fluctuation. Natural ventilation is the common and cheapest method to cooling down temperature in greenhouse. It driven forces is the pressure differences that created and maintained by wind or temperature gradients. This method uses thermal gradients, creating circulation due to warm air rising.

Additional cooling is needed when regular ventilation unable to provide sufficient cooling for greenhouse [15]. Ventilation for greenhouse that is 100 feet below can be accomplished by mounting pressure fans, which blow air into the greenhouse. Distribution air inside the greenhouse is important because to maintain crop production when every plant experiences the same environmental conditions. Thus, horizontal airflow fans are installed to ensure proper air mixing [3]. Medium and large size of greenhouse need a good ventilation system and natural forced such as wind is insufficient. As the size of greenhouse increase, the need for ventilation usually increases and exhaust fans are needed to enhance and maintain temperature in the greenhouse [16].

Fan in the end wall is the most common method of forced ventilation system as shown in Figure 1. The exhaust fan should be able to move the air inside the greenhouse and exchange with the outside air. One air exchange per minute should keep $8^{\circ} \mathrm{C}$ higher than outside temperature [17]. 

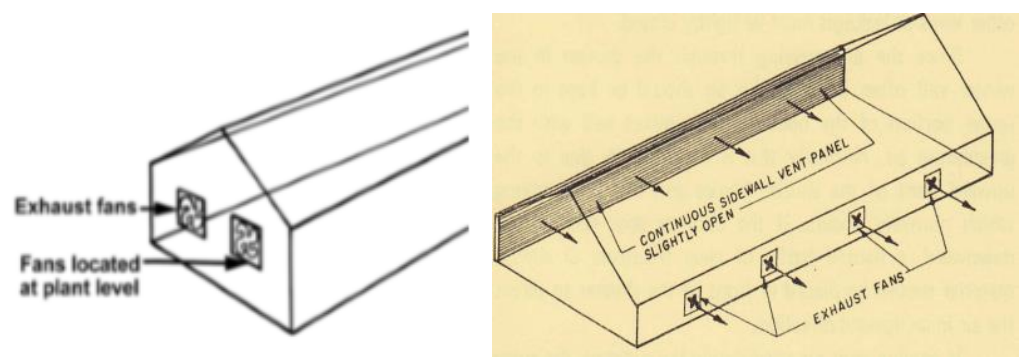

Figure 1. End wall exhaust fan (left) and Sidewall exhaust fan (right)

In some greenhouse the fans are placed sidewall as shown in Figure 2. This method is used when different temperature levels are desired along the greenhouse. The main problem for this method is; if the fan spacing along the wall to far each other, a dead air space occurs between the fan on the fan side of greenhouse. The maximum spacing for sidewall spacing fan should be 25 feet or less [13].

The objective of this research is to design an automatic ventilation control system to achieve optimum temperature for tomato cultivation and reduce energy consumption in the greenhouse. The control mechanism is tested on a tomato greenhouse which has a total area of $100 \times 20 \mathrm{~m} 2$ located in Universiti Putra Malaysia (UPM), Serdang. The greenhouse has a height of 14 feet from ceiling to bottom, 20 feet wide and 100 feet length and covered using polyethylene plastic. The ventilation system in the greenhouse comprises of six exhaust fans and two axial fans. Temperature sensor (DHT22) is installed in the greenhouse to measure the temperature inside the greenhouse. Data from the sensors are sent to Arduino and the Arduino will control the fans operation using relays according to the temperature in the greenhouse. A set of coding for the control mechanism are written and programmed in the Arduino. Finally, temperature and energy consumption in the greenhouse are analysed.

\section{RESEARCH METHOD}

The methodology in this study comprises of three main components i.e. 1) overall system block diagram, 2) ventilation control algorithm and 3) hardware implementation.

\subsection{System Block Diagram}

Figure 2 shows the block diagram of the ventilation control system in the greenhouse. The system comprises of temperature sensors, exhaust fans, axial fans, Arduino microcontroller, real time clock, SD card module and relay module. The system development is divided into software and hardware parts. The software part involved the development of programming for the microcontroller. Meanwhile for the hardware part consisted of the interfacing microcontroller and the ventilation system. This project develops an optimum algorithm to control the temperature inside the greenhouse using ventilation system at low energy use.

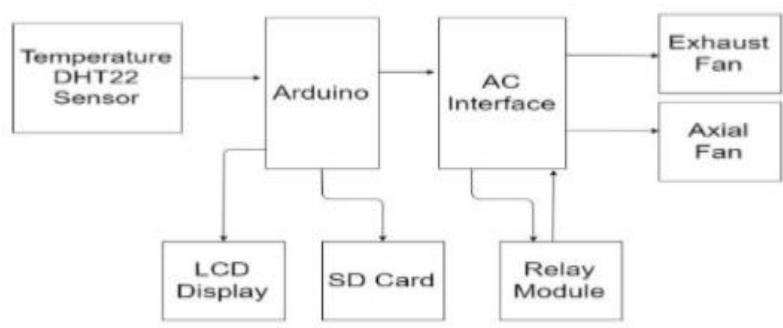

Figure 2. System Block Diagram

In this system, the sensors sense the change in temperature and send to Arduino. Arduino acts as microcontroller reads this form information from its data port performs the required condition to control the fans. The control conditions of the fans are displayed through the LCD installed at the Arduino and saved in secure digital card (SD card). 


\subsection{Ventilation Control Algorithm}

Figure 3 shows the flowchart of the control algorithm. The system will first receive temperature signal from three DHT22 sensors located in three different zones in the greenhouse i.e. left end, middle and right end. The signal will be interpreted and processed by the Arduino which performs as microcontroller. The signal will become command to control the exhaust fans and axial fans. The LCD will display the three temperature zones as Temp 1, Temp 2 and Temp 3. Average temperature inside the greenhouse is calculated from the three temperature readings. If one of the DHT22 sensors do not get the reading, the average temperature will not be displayed in LCD and the controller will set to the previous condition.

Three conditions are set to control the design controller as summarized in Table 2. For the first condition, when the average temperature is below $25^{\circ} \mathrm{C}$ all the fans are set to turn OFF by the relay. Second condition is when the average temperature is between $25^{\circ} \mathrm{C}$ and $33^{\circ} \mathrm{C}$, only the exhaust fans are turn ON. Third condition is when the average temperature is higher than $33^{\circ} \mathrm{C}$, all the fans (exhaust and axial fans) are turn ON. The LCD will display the average temperature and the fans condition. The average temperature data is recorded in the SD card.

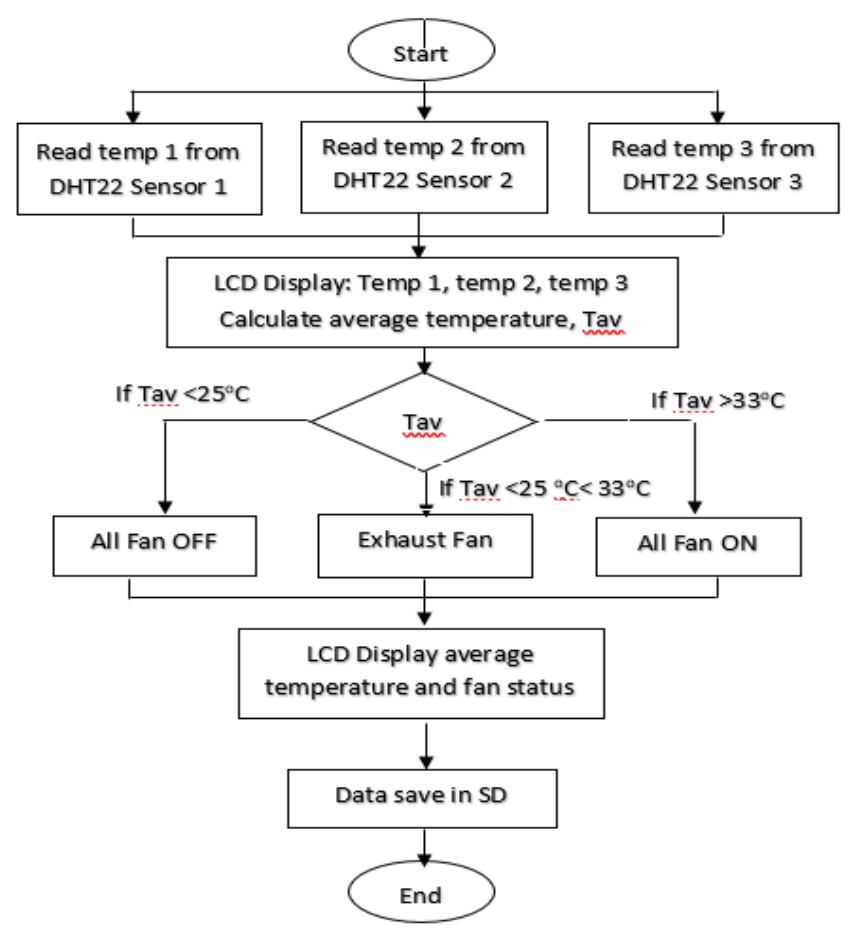

Figure 3. Flowchart for the control algorithm

Table 2. Control mechanism for greenhouse temperature conditions

\begin{tabular}{lll}
\hline Condition & Temperature & Control Mechanism \\
\hline 1 & $<25^{\circ} \mathrm{C}$ & all fans are turn OFF \\
2 & $25^{\circ} \mathrm{C}$ and $33^{\circ} \mathrm{C}$ & exhaust fans are turn ON, axial fans are turn OFF \\
3 & $>33^{\circ} \mathrm{C}$ & all fans are turn ON \\
\hline
\end{tabular}

\subsection{Hardware Implementation}

The hardware of this project has been developed at Universiti Putra Malaysia (UPM), Serdang. The ventilation system consists of axial and exhaust fan where their specifications are shown in Table 3 . Figure 4 shows the axial and exhaust fan arrangement in the greenhouse.

Table 3. Ventilation devices specifications

\begin{tabular}{cccc}
\hline Ventilation & No & Size $(\mathrm{kW})$ & Model \\
\hline Axial Fan & 2 & $400 \mathrm{~W}$ & MSA400Fq \\
Exhaust Fan & 4 & $60 \mathrm{~W}$ & KDK 12 inch \\
\hline
\end{tabular}



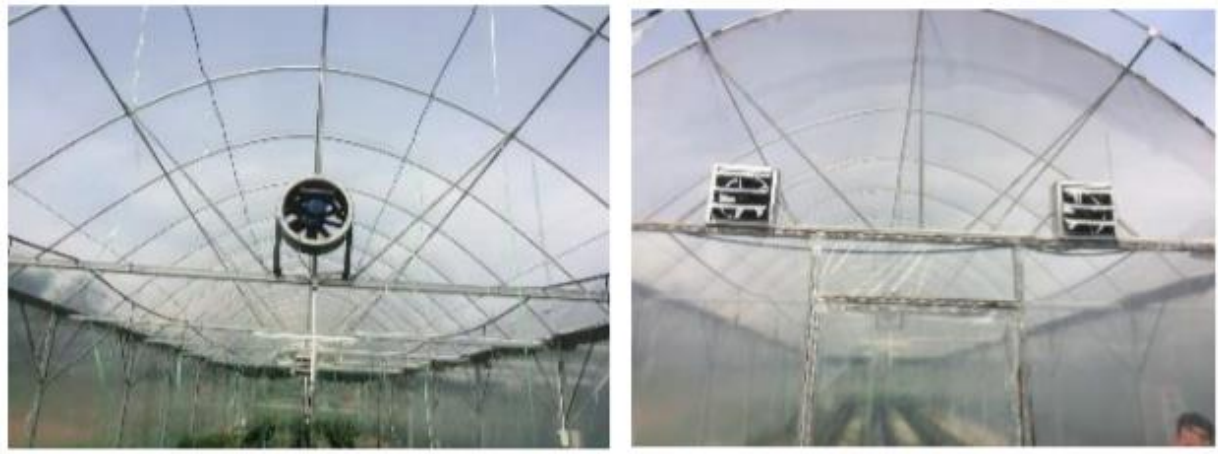

Figure 4. Axial fan (left) and exhaust fan (right) arrangement in the greenhouse

Figure 5 shows the control panel for controlling parameters in the greenhouse. There are two controls switches for ventilation system; 1) the exhaust fans which are controlled at Fan-1 switch and 2) axial fan which are controlled at Fan-2 switch.

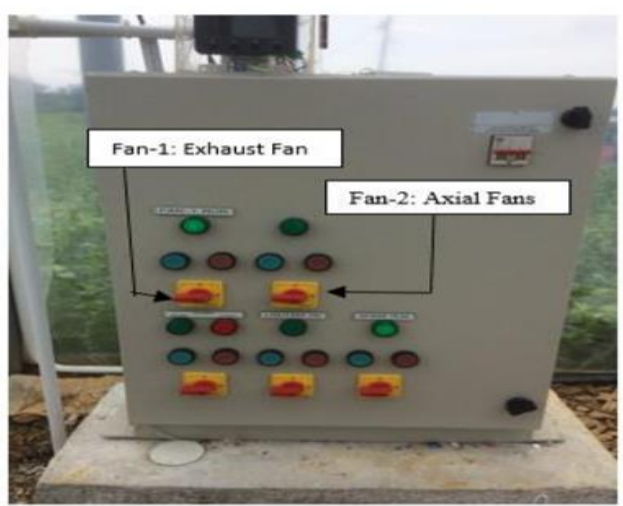

Figure 5. Control Panel located inside the greenhouse

\section{RESULTS AND ANALYSIS}

Figure 6 (left) shows the introduction interface of the ventilation controlling system on the LCD attached with monitoring and controlling device installed in the greenhouse. The LCD displays the introduction text "Fan Controlling System", actual date and time that programmed in the real time clock (RTC1302). On the other hand, Figure 6 (right) shows the temperature reading at a particular time for the three zones from each DHT22 sensors. The reading indicates that temperature at zone 1 i.e. Temp 1 is $38.8^{\circ} \mathrm{C}$, zone 2 i.e. Temp 2 is $40.20^{\circ} \mathrm{C}$ and zone 3 i.e. Temp 3 is $37.40^{\circ} \mathrm{C}$.

Figure 7 (left) shows the condition status of the fans. For example, in the figure, the LCD shows the average temperature from the three zones is $31 \mathrm{oC}$. When the average temperature is between $25^{\circ} \mathrm{C}$ and $33^{\circ} \mathrm{C}$, the control system set all the exhaust fans to turn $\mathrm{ON}$ condition and the axial fans to OFF condition. On the other hand, when the average temperature in the greenhouse is higher than $33^{\circ} \mathrm{C}$ i.e. $38^{\circ} \mathrm{C}$ as shown in Figure 7 (right), all the fans i.e. exhaust, and axial are turned on.

Figure 8 (left) shows that the average temperature is saved in the SD card. "Successfully Recorded" will be displayed if the data is successful saved. In Figure 8 (right), the LCD displays "nan" value from zone 3 when there is error in reading the temperature from the sensor.

Energy and temperature data were collected from the greenhouse on two consecutive days on 21st and 22nd May 2018. Figure 9 shows the plot of temperature reading inside and outside the greenhouse for the two days. It is observed that at 9.00 am to $3.00 \mathrm{pm}$ the inside temperature is higher than outside temperature. The peak temperature was between $11 \mathrm{am}$ to $1.00 \mathrm{pm}$ for the two days. The highest temperature inside the greenhouse on the $21 \mathrm{st}$ May 2018 was $39.13^{\circ} \mathrm{C}$ while the lowest temperature was $25.03^{\circ} \mathrm{C}$. On the other hand, the highest temperature inside the greenhouse on the $22 \mathrm{nd}$ May 2018 was $38.97^{\circ} \mathrm{C}$ while the lowest temperature was $24.73^{\circ} \mathrm{C}$. 

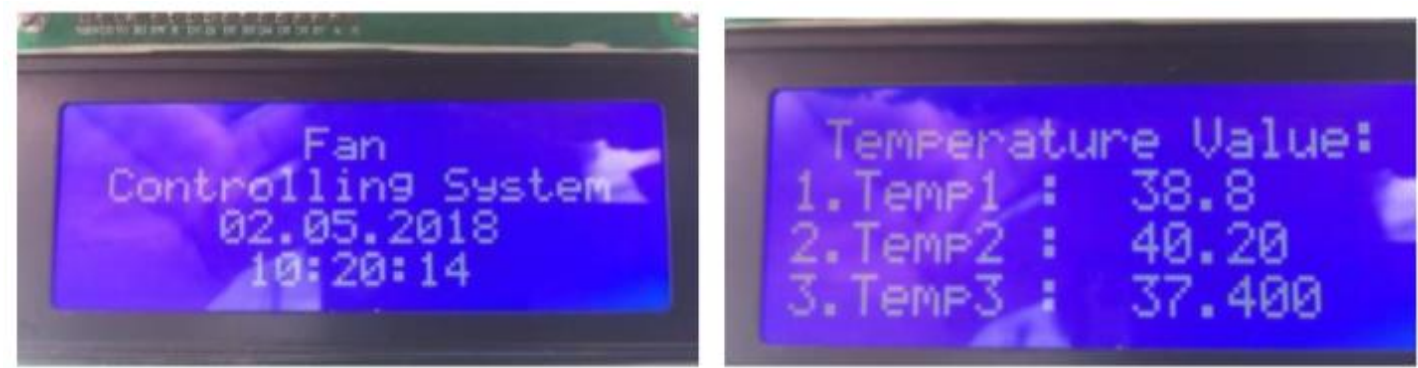

Figure 6. Introduction interface (left) and temperature readings for three zones (right)
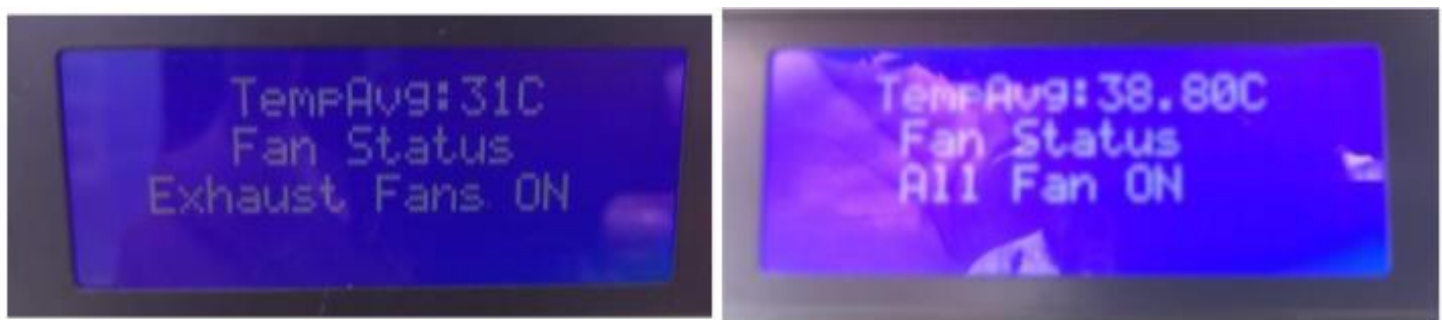

Figure 7. Fan status when the average temperature between $25^{\circ} \mathrm{C}$ and $33^{\circ} \mathrm{C}$ (left) and temperature is higher than $33^{\circ} \mathrm{C}$ (right)
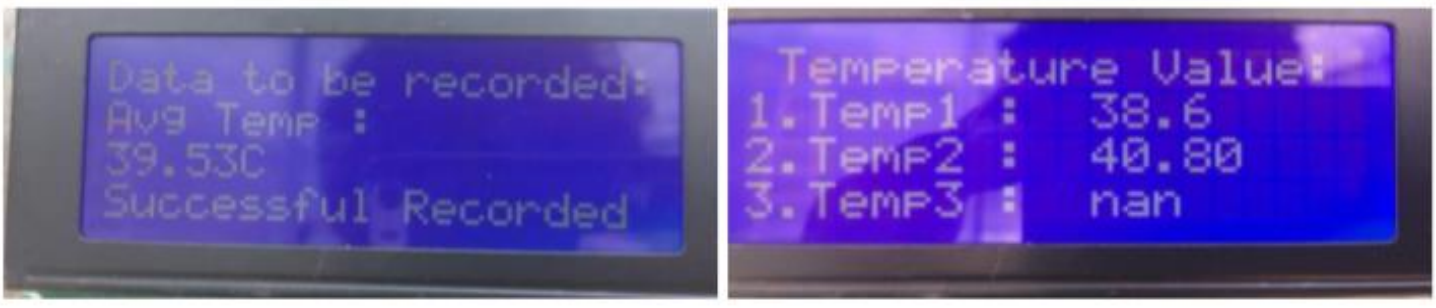

Figure 8. Average temperature is saved in SD card (left) and error temperature reading (right)

From the data analysis, the control ventilation system can provide the desired temperature for the tomato. Although the temperature inside the greenhouse is higher than the outside temperature during the hot time, the temperature still can be maintained below the $\max 40^{\circ} \mathrm{C}$ as required by tomato production. Before the ventilation system was installed in the greenhouse, the max temperature recorded in the greenhouse was $60^{\circ} \mathrm{C}$.
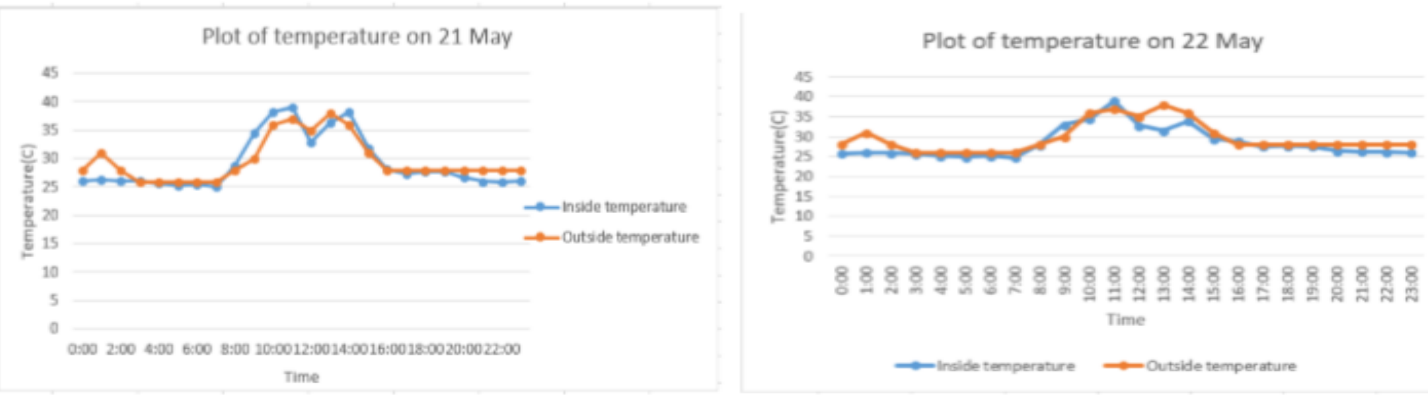

Figure 9. Plot of temperature inside and outside of the greenhouse on 21 May 2018 (left) and 22 May 2018 (right) 


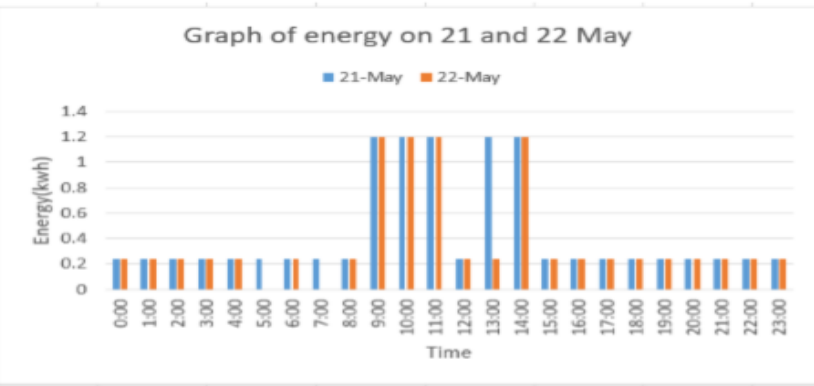

Figure 10. Graph of energy consumption in the greenhouse on 21 and 22 May

\section{CONCLUSION}

This paper presents an automatic system to control temperature in a greenhouse located at Universiti Putra Malaysia. The ventilation system in the greenhouse comprises of six exhaust fans and two axial fans. Three conditions are set to control the design controller. For the first condition, when the average temperature is below $25^{\circ} \mathrm{C}$ all the fans are set to turn OFF by the relay. Second condition is when the average temperature is between $25^{\circ} \mathrm{C}$ and $33^{\circ} \mathrm{C}$, only the exhaust fans are set to turn $\mathrm{ON}$ and the axial fan are set to turn OFF. Third condition is when the average temperature is higher than $33^{\circ} \mathrm{C}$, all the fans (exhaust and axial fans) are set to turn ON. Using this control algorithm, the temperature inside the greenhouse was able to be controlled to achieve the temperature required for tomato growth. The proposed ventilation control system effectively provides a proper climate for greenhouse production of tomato in lowland.

From the results, with the automatic ventilation system the energy usage could be saved with average of $65.8 \%$ as compare to the baseline energy without the control system. With a good automatic system not only, the required temperature inside the greenhouse can be achieved but the energy also can be minimized.

\section{ACKNOWLEDGEMENT}

We would like to thank Universiti Tenaga Nasional (UNITEN) who has sponsored this paper under UNITEN Multi Track Incentive under the BOLD2025 initiative.

\section{REFERENCES}

[1]. M. Mancuso, V. Aprile, V. Ragusa, and V. Pianazze. "A Wireless Sensors Network for Monitoring Environmental Variables in a Tomato Greenhouse". IEEE Int. Work. Fact. Communication. Syst. - WFCS, pp. 107-110, 2011.

[2]. R. A. Li, X. Sha, and K. Lin. "Smart greenhouse: A real-time mobile intelligent monitoring system based on WSN". IWCMC 2014 - 10th Int. Wireless. Communication. Mob. Computer. Conf., pp. 1152-1156, 2014.

[3]. A J. Both, "Greenhouse Temperature Management," Greenhouse. Energy Cost Reduction. Strategy., pp. 1-4, 2008.

[4]. G. T. Hydroponically, P. One, M. Jensen, U. States, R. E. Tiberius, and E. M. Emmert. "Growing hydroponic tomatoes". 1948.

[5]. D. Rutledge. "Commercial Greenhouse Tomato Production". Univ. Tennessee, no. PB 1609, 2014.

[6]. Starke Ayres. Tomato Production Guideline. Memb. Plennegy Gr., pp. 1-11, 2014.

[7]. Department of Agriculture Forestry and Fisheries. "Production guidelines for Tomato". Prod. Guidel., pp. 1-13, 2012.

[8]. S. Alyousif. "Intelligent Temperature Control System at Greenhouse". International Journal of Computer Applications. Vol. 12, no. 9, pp. 1811-1814, 2017.

[9]. of and T. H. E. Industry. "Greenhouse Tomato Production”. pp. 257-304, 2005.

[10]. H. C. Practices. "High-tech Cultivation Practices".

[11]. E. USAID, WUR, "Cultivation of Tomato", vol. 31, no. 8. 2017.

[12]. S. Nicola, G. Tibaldi, and E. Fontana. "Tomato production systems and their application to the tropics". Acta Hortic. vol. 821, no. August 2015, pp. 27-33, 2009.

[13]. H. A. Jackson and D. E. Darby. Greenhouse ventilation. Canada Plan Serv., vol. M-6704, no. M-6704, 1980.

[14]. S. Sanford. "Reducing greenhouse energy consumption-An overview". Energy Efficiency. Greenhouses, pp. 1-16, 2011.

[15]. H. Li and S. Wang. "Technology and Studies for Greenhouse Cooling”. World J. Eng. Technol. vol. 3, no. 3, pp. 73-77, 2015

[16]. M. Karlsson, “Controlling the greenhouse environment,” Univ. Alaska, pp. 1-18, 2014.

[17]. Worley, "GREENHOUSES Heating, Cooling and Ventilation," 2011.

[18]. Impron, "A Greenhouse Crop Production System for Tropical Lowland Conditions,” p. 117, 2011. 